\title{
GERMINAL CELL LOSS DURING HUMAN SPERMATOGENESIS
}

\author{
ARNOLD B. BARR, DONALD J. MOORE* AND \\ C. ALVIN PAULSEN* \\ U.S. Public Health Service Hospital, Staten Island, New York, \\ Department of Anatomy, McGill University, Montreal, Quebec, and \\ *Department of Medicine, University of Washington, Seattle, Washington
}

(Received 2nd June 1970, revised 27th August 1970)

\begin{abstract}
Summary. Testicular biopsy specimens from fifteen normal adult men were analysed histologically, using Glermont's classification for the germ cell types. After corrections were made for differences in nuclear size and life-span, spermatid/primary spermatocyte ratios ranging from 0.87 to 3.82 (average 2.58 ) were found. This represents a marked reduction from the theoretical ratio of 4.0 which would be expected. The significance of this attrition rate, or the point at which loss occurs, is not known.
\end{abstract}

\section{INTRODUCTION}

Glermont (1963) clearly demonstrated that human spermatogenesis is not a disorganized process and provided the basis for a rational understanding of the human germinal epithelium. He definitively described the various germ-cell types and showed that the germinal epithelium was organized into recognizable cellular associations or stages, which related to the process of germ-cell maturation. Later, Heller \& Glermont (1964) determined the duration of spermatogenesis. Their data also defined the kinetics of individual germ-cell maturation, as well as of the spermatogenic stages.

With this information as a guide-line, the present study was instituted to determine whether or not the observed yield of spermatids from primary spermatocytes during normal human spermatogenesis coincided with the theoretical $4: 1$ ratio that would be expected.

\section{MATERIALS AND METHODS}

Eighteen testicular biopsy specimens were obtained from fifteen normal inmate volunteers. The means of ten or more control sperm counts for each individual ranged from 42 to 239 million spermatozoa $/ \mathrm{ml}$ of ejaculate. Urinary follicle-stimulating hormone (FSH) excretion, determined by the method of Steelman \& Pohley (1953), ranged from 2.9 to $26 \cdot 3$ i.u./24 hr for twelve individuals (in our laboratory the normal range is from 1.8 to 26 i.u. $/ 24 \mathrm{hr}$ ). In 
three individuals, general gonadotrophin $(\mathrm{FSH}+\mathrm{LH}$ ) levels varied from 1.2 to $3.8 \mathrm{mg}$-equiv.UPM-1/24 hr, which is within our normal range. (UPM-1 is the general gonadotrophin standard supplied by the Endocrine Study Section, National Institute of Arthritis and Metabolic Diseases, Bethesda, Maryland.) The biopsies were performed using the technique described by Paulsen (1968), where the specimen is placed into either Gleland's or Zenker's formol fixative, embedded, cut and stained.

Germinal cells were identified and counted according to the classification of Clermont (1963). All cells in from ten to 100 seminiferous tubules per biopsy specimen were counted. In those specimens, where the smaller number of tubules was scored, ten normal-sized circular tubules were randomly selected for quantification from low-power photomicrographs. In other specimens, all circular tubules without artifacts were scored, up to a total of 100 per single cross-section. Seminiferous tubules regarded as exhibiting technical artifacts were discarded from further consideration.

Only the counts for primary spermatocytes and spermatids are presented here. Counts of the various types of spermatogonia are not included because there is not sufficient information to detail their relative life-spans.

TABLE 1

ABERGROMBIE CORRECTION FAGTORS FOR VARIOUS GERM-CELL TYPES

\begin{tabular}{|c|c|c|c|c|c|c|c|c|c|c|}
\hline \multirow{2}{*}{ Fixative } & \multicolumn{4}{|c|}{ Spermatocytes } & \multicolumn{6}{|c|}{ Spermatids } \\
\hline & $R$ & $L$ & $z$ & $P$ & $S a$ & $S b_{1}$ & $S b_{2}$ & $S c$ & $S d_{1}$ & $S d_{2}$ \\
\hline $\begin{array}{l}\text { Zenker-formol } \\
\text { Cleland }\end{array}$ & $\begin{array}{l}0.50 \\
0.47\end{array}$ & $\begin{array}{l}0.40 \\
0.40\end{array}$ & $\begin{array}{l}0.39 \\
0.39\end{array}$ & $\begin{array}{l}0.37 \\
0.36\end{array}$ & $\begin{array}{l}0.50 \\
0.50\end{array}$ & $\left(_{0.53}^{*}\right.$ & $\begin{array}{l}0.55) \\
0.59\end{array}$ & $\begin{array}{l}0.67 \\
0.63\end{array}$ & $\begin{array}{l}0.71 \\
0.70\end{array}$ & $\begin{array}{l}0.71 \\
0.70\end{array}$ \\
\hline Combined groups & & 0.42 & & 0.36 & & 0.51 & & & 0.68 & \\
\hline
\end{tabular}

* Under Zenker-formol fixation, $\mathrm{Sb}_{1}$ spermatids cannot be easily distinguished from $\mathrm{Sb}_{2}$ spermatids; therefore these two classifications were combined.

To correct for differences in nuclear size, at least twenty typical representatives of each type of spermatocyte and spermatid from both Cleland- and Zenker-formol-fixed material were measured to determine their average nuclear diameter. The diameters were measured in both axes in most cells; it was then assumed that these nuclei were perfect spheres. In the instance of $\mathrm{Sc}, \mathrm{Sd}_{1}$ and $\mathrm{Sd}_{2}$ spermatids, measurements were based on their width only. This experimentally determined figure for each cell type was then used to calculate the correction factors for relative nuclear size using the formula of Abercrombie (1946):

$$
\mathrm{TC}=\mathrm{GG} \times \frac{\mathrm{S}}{\mathrm{S}+\mathrm{D}}
$$

where $\mathbf{T C}=$ true count, $\mathbf{C G}=$ crude count, $\mathrm{S}=$ section thickness and $\mathrm{D}=$ nuclear diameter perpendicular to the plane of section of the tissue. This correction factor, when applied to the various cell classifications or groups, is shown in Table 1.

The life-span for primary spermatocytes has been estimated to be 23.5 


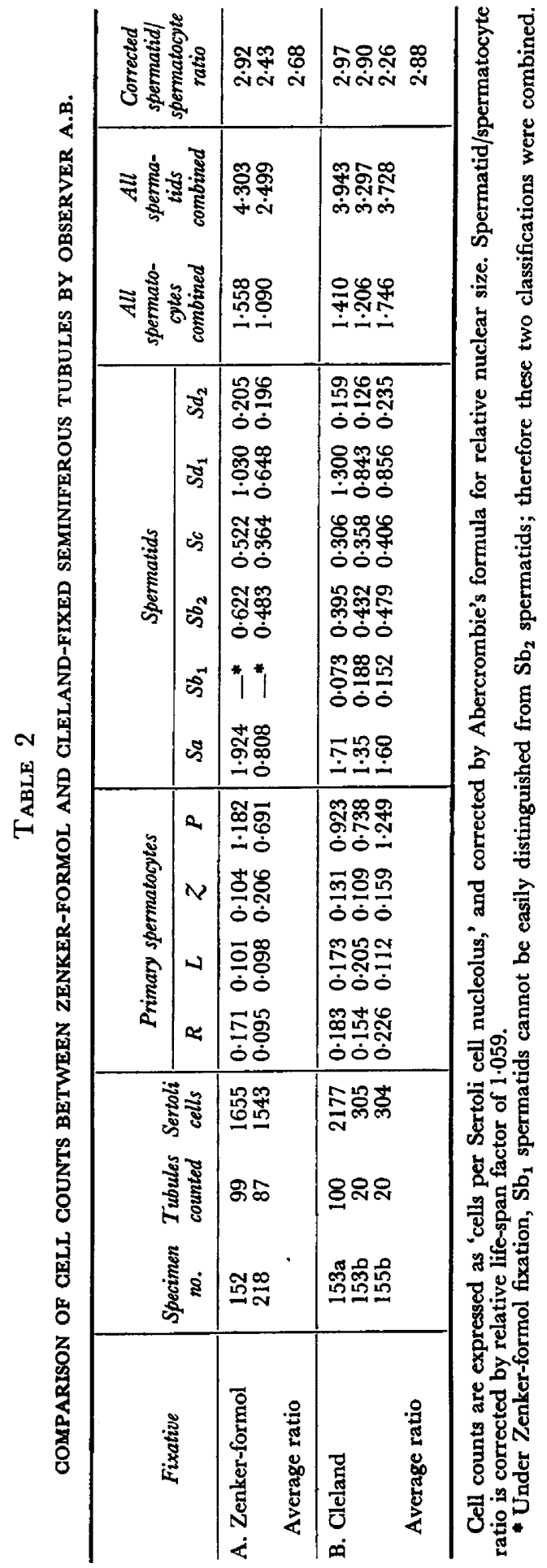


days (Heller \& Clermont, 1964) and that for spermatids, 22.2 days; therefore, a further correction factor of $23.5 / 22.2$, or 1.059 has been inserted into the ratio calculations to adjust for this difference.

Tubules were scored by three different observers (D.M., M.G. and A.B.). Observers D.M. and M.C. grouped preleptotene (R), leptotene (L) and zygotene $(Z)$ spermatocytes, while listing pachytene $(P)$ spermatocytes separately; likewise $\mathrm{Sa}$ and $\mathrm{Sb}$ spermatids, and $\mathrm{Sc}, \mathrm{Sd}_{1}$ and $\mathrm{Sd}_{2}$ were grouped in their scoring. Account was made of the differing nuclear diameters for each group by determining an 'average' correction factor based on the mean diameter of each cell type.

Observer A.B. expressed his counts as the specific cell type per Sertoli cell nucleolus; D.M. and M.G. expressed their counts as the number of a specific cell type per circular tubule. The counts for each type of spermatocyte, corrected by Abercrombie's formula, were then added together for each specimen; the same was done for the spermatids. The ratio of spermatids to spermatocytes, multiplied by the inverse ratio of their life-spans, was then calculated.

\section{RESULTS}

The corrected mean counts for the various cell types scored in each specimen are listed in Tables 2 and 3 . Table 2 compares two different fixatives and Table 3

TABLE 3

COUNTS OF PRIMARY SPERMATOCYTES AND SPERMATIDS FROM CLELAND-FIXED MATERIAL

\begin{tabular}{|c|c|c|c|c|}
\hline & Specimen no. & $\begin{array}{c}\text { All primary } \\
\text { spermatocytes } \\
\text { combined }\end{array}$ & $\begin{array}{c}\text { All } \\
\text { spermatids } \\
\text { combined }\end{array}$ & $\begin{array}{c}\text { Corrected } \\
\text { spermatid/spermatocyte } \\
\text { ratio }\end{array}$ \\
\hline $\begin{array}{l}\text { A. Counts by Observer A.B. } \\
\text { expressed as 'cells per Sertoli } \\
\text { cell nucleolus' } \\
\text { Average ratio }\end{array}$ & $\begin{array}{r}84 \\
86 \\
135 \\
151 \\
153 \\
155 \\
158\end{array}$ & $\begin{array}{l}0.872 \\
1.310 \\
0.831 \\
1.553 \\
1.308 \\
1.600 \\
1.122\end{array}$ & $\begin{array}{l}3 \cdot 141 \\
3 \cdot 286 \\
2 \cdot 422 \\
4 \cdot 382 \\
3 \cdot 615 \\
3 \cdot 776 \\
2 \cdot 214\end{array}$ & $\begin{array}{l}3 \cdot 82 \\
2 \cdot 66 \\
3 \cdot 10 \\
2 \cdot 99 \\
2 \cdot 92 \\
2 \cdot 50 \\
2 \cdot 09 \\
2 \cdot 87\end{array}$ \\
\hline $\begin{array}{l}\text { B. Counts by Observers D.M. } \\
\text { and M.C. expressed as 'cells per } \\
\text { tubule' }\end{array}$ & $\begin{array}{r}84 \\
86 \\
133 \\
135 \\
151 \\
155 \\
158 \\
188 \\
192 \\
208 \\
217 \\
246 \\
304 \\
310 \\
372\end{array}$ & $\begin{array}{l}19 \cdot 21 \\
18.02 \\
18.06 \\
14.13 \\
19.29 \\
19.63 \\
16.08 \\
18.31 \\
20.58 \\
12.98 \\
17.78 \\
18.32 \\
18.26 \\
17.99 \\
18.91\end{array}$ & $\begin{array}{l}61 \cdot 42 \\
42.94 \\
50.76 \\
34.58 \\
47.72 \\
49.50 \\
32.90 \\
28.37 \\
45 \cdot 07 \\
26 \cdot 25 \\
60.77 \\
15 \cdot 11 \\
46.57 \\
30 \cdot 87 \\
48.72\end{array}$ & $\begin{array}{l}3.39 \\
2.52 \\
2.98 \\
2.59 \\
2.61 \\
2.67 \\
2.17 \\
1.64 \\
2.32 \\
2 \cdot 14 \\
3.62 \\
0.87 \\
2.70 \\
1.82 \\
2.73 \\
2.45\end{array}$ \\
\hline Average ratio & & & & $2 \cdot 45$ \\
\hline
\end{tabular}

Cell counts are corrected by Abercrombie's formula for relative nuclear size. The ratio is corrected by the relative life-span factor, 1.059 . 
compares two methods for deriving the spermatid/spermatocyte ratio. There was considerable variability in the counts of individual cell types between specimens. Less variability was noted when total spermatocytes and total spermatids were compared, but the range was still considerable. These observations receive further comment later.

A.B. (Tables 2 and 3) used Sertoli cells as his reference point; D.M. and M.G. (Table 3) expressed their results as counts per tubule. Thus, while the total counts cannot be directly compared, the derived ratios are comparable between the two methods.

The most informative data are the ratios given in the last column of each table where, for each specimen, total primary spermatocytes are divided by total spermatids and multiplied by the correction factor for the relative lifespans of these cell types. A.B. (Table 3 ) found an average spermatid/spermatocyte ratio of 2.87 (range 2.09 to 3.82), while D.M. and M.G. obtained an average ratio of 2.45 (range 0.87 to 3.62 ) by the 'per tubule' technique.

The ratio of spermatids to primary spermatocytes (Sp/Psp) should theoretically be $4 \cdot 0$, as each primary spermatocyte divides twice before reaching the spermatid stage. However, in all specimens scored, the mean $\mathrm{Sp} / \mathrm{Psp}$ ratios were less than 4 . Indeed, in the majority of observations, eighteen out of twenty-two demonstrated $\mathrm{Sp} / \mathrm{Psp}$ ratios of less than 3.0.

These data indicate that there is a variable, but significant, loss of potential spermatids during normal human spermatogenesis.

\section{DISCUSSION}

The human testis does not easily lend itself to statistical analysis; quantification in other mammals is simple by comparison. This is, in great part, due to the 'mixing' of several stages of the cycle of the seminiferous epithelium in any given tubular cross section (Clermont, 1963). Large standard deviations in the average counts of the various types of spermatogonia, spermatocytes and spermatids have been observed by us and by others (Tjioe, Steinberger \& Paulsen, 1967; Steinberger \& Tjioe, 1968), even when relatively large numbers of tubules were counted in a single biopsy specimen. The possible reasons for this variability and the statistical problems involved in the quantification of human spermatogenesis have recently been discussed by Steinberger \& Tjioe (1968). Examination of our tables shows that the range of the observed data from specimen to specimen is wide. However, the consistent and important finding is that, in each specimen examined, significant numbers of potential spermatids are lost.

A similar quantification of spermatogenesis has been performed in the mouse (Oakberg, 1956), the rat (Glermont, 1962) and the bull (Ortavant, 1963). In these mammals, significant numbers of spermatocytes and spermatids degenerate, mostly during the reduction divisions. The present data show that large numbers of human germinal cells are similarly lost.

Confirmation of these data comes from two other sources. When human seminiferous tubules are prepared by a special 'whole-tubular mount' technique, 
degenerating spermatogonia, spermatocytes and spermatids can frequently be directly observed (Barr, 1967). Secondly, chromosomal abnormalities are seen in spermatocytes during meiotic metaphase and diakinesis in testicular biopsy specimens from males with normal spermatogenesis (Swersie \& Paulsen, 1968). This suggests that some of the germinal cell loss occurs in the human during the reduction divisions. Neither the physiological basis nor the biological importance of this large loss of germinal cells in man and in other mammals is known at the present time.

\section{ACKNOWLEDGMENTS}

This study was supported, in part, by grants AT(45-1)-2225, Task Agreement 6, U.S. Atomic Energy Commission; RO1 AM 05436 and TO1 AM 05161 from the National Institutes of Health, Bethesda, Maryland. Appreciation is expressed to Dr Yves Glermont, Professor of Anatomy, McGill University, Montreal, under whose guidance much of the work was carried out during the tenure of a post-doctoral fellowship. We also wish to thank Margaret Couture for her fine technical assistance.

\section{REFERENCES}

Abercrombie, M. (1946) Estimation of nuclear population from microtome sections. Anat. Rec. 94, 238. BARR, A. B. (1967) Human spermatogenesis. M.Sc, thesis, McGill University.

Clermont, Y. (1962) Quantitative analysis of spermatogenesis of the rat: a revised model for the renewal of spermatogonia. Am. F. Anat. 111, 111.

Clermont, Y. (1963) The cycle of the seminiferous epithelium in man. Am. 7. Anat. 112, 35.

Heller, C. G. \& Clermont, Y. (1964) Kinetics of the germinal epithelium in man. Recent Prog. Horm. Res. 20, 545.

OAKBERG, E. F. (1956) A description of spermatogenesis in the mouse and its use in analysis of the cycle of the seminiferous epithelium and germ cell renewal. Am. F. Anat. 99, 391.

Ortavant, R. (1963) Le cycle spermatogénétique chez le belier. Thése, Faculté des Sciences, Université de Paris, 1958. Quoted by Leblond, C. P., Steinberger, E. \& Roosen-Runge, E. C. In: Mechanisms concerned with conception, pp. 1-72. Ed. G. G. Hartman. Pergamon Press, New York.

Paulsen, C. A. (1968) The testes. In: Textbook of Endocrinology, Chapter 6, p. 405. 4th edn., Ed. R. H. Williams. Saunders, Philadelphia.

Steelman, S. L. \& Pohley, F. M. (1953) Assay of the follicle stimulating hormone based on the augmentation with human chorionic gonadotropin. Endocrinology, 53, 604.

Steingerger, E. \& TJIOE, D. Y. (1968) A method for quantitative analysis of human seminiferous epithelium. Fert. Steril. 10, 960.

SWErsie, S. P. \& PAulsen, C. A. (1968) Structural abnormalities of germ-cell chromosomes in men with normal spermatogenesis. 3rd Int. Congr. Endocrinology, Mexico City, Abstract 59. Published in Excerpta Medica, Intn. Congr. Series No. 157.

Tyroe, D. Y., Steinberger, E. \& Paulsen, C. A. (1967) A simple method for quantitative analysis of seminiferous epithelium in human testicular biopsies. F. Albert Einstein med. Cent. 15, 56. 